\title{
Role of zooplankton in the onset and demise of harmful brown tide blooms (Aureococcus anophagefferens) in US mid-Atlantic estuaries
}

\author{
Sarah N. Deonarine ${ }^{1}$, Christopher J. Gobler ${ }^{1, *}{ }^{\text {, Darcy J. Lonsdale }}{ }^{1}$, David A. Caron ${ }^{2}$ \\ ${ }^{1}$ Marine Sciences Research Center, Stony Brook University, Stony Brook, New York 11794-5000, USA \\ ${ }^{2}$ Department of Biological Sciences, University of Southern California, Los Angeles, California 90089-0371, USA
}

\begin{abstract}
Harmful brown tides caused by the pelagophyte Aureococcus anophagefferens have occurred in mid-Atlantic estuaries for 2 decades. Low grazing rates by microzooplankton have been implicated as a possible cause of these events, but no study to date has concurrently quantified zooplankton population densities and zooplankton grazing rates of $A$. anophagefferens cells. We conducted field studies from 2002 to 2004 to quantify grazing on the brown tide alga A. anophagefferens by meso-, micro-, and nanozooplankton, while concurrently establishing the composition of the plankton community. Research sites included an estuary that experienced an intense brown tide (Chincoteague Bay, Maryland [MD]; 2004: $2 \times 10^{6} \mathrm{cells} \mathrm{m}^{-1}$ ) and one that experienced sporadic blooms (Quantuck Bay, New York [NY]; 2002: $8 \times 10^{5}$ cells ml $^{-1}$; 2003 and 2004: $<3 \times 10^{4}$ cells ml$^{-1}$ ). The MD site was dominated by small autotrophs $(<5 \mu \mathrm{m})$, such as A. anophagefferens and other picoeukaryotes, and small heterotrophs, such as Paulinella ovalis, while the NY site hosted a range of large and small autotrophs and zooplankton. Experiments indicated that small zooplankton (3 to 5 $\mu \mathrm{m})$ were consumers of $A$. anophagefferens at bloom and non-bloom locations. However, dilution experiments documented active grazing on most picoplankton except $A$. anophagefferens in $\mathrm{MD}$, while grazing rates on the brown tide alga in NY were comparable to grazing rates on the total phytoplankton community and other picoplankton. Experimental enrichment of estuarine waters with mesozooplankton indicated a preferential avoidance of $A$. anophagefferens by grazers during intense blooms, but active consumption during non-bloom conditions. Differences in the effect of grazing between sites suggest that zooplankton may be controlling brown tides in NY, but allowing blooms to form due to low grazing pressure in MD. These findings further suggest that the zooplankton community in NY has changed from one which formerly avoided the consumption of A. anophagefferens to one which currently contributes to top-down control of brown tides.
\end{abstract}

KEY WORDS: Harmful algal blooms - Brown tide - Aureococcus anophagefferens · Zooplankton · Grazing $\cdot$ Trophic cascade $\cdot$ Paulinella ovalis $\cdot$ Synechococcus sp.

\section{INTRODUCTION}

The picoplanktonic pelagophyte Aureococcus anophagefferens Hargraves et Sieburth is responsible for harmful brown tides in mid-Atlantic estuaries of the US (reviewed in Gobler et al. 2005). A. anophagefferens is considered harmful due to its detrimental effects on eelgrass Zostera marina beds, shellfish populations, and zooplankton. Significant reduction in light penetration during intense blooms $\left(10^{6}\right.$ cells $\left.\mathrm{ml}^{-1}\right)$ has caused die-offs of eelgrass (reviewed in Gobler et al. 2005), and feeding cessation and mortality have been noted for suspension-feeding shellfish (Greenfield \& Lonsdale 2002, Gobler et al. 2005). Successive brown tides in the 1980s led to the collapse of Long Island's bay scallop Argopecten irradians fishery, and blooms 
have negatively affected the hard clam Mercenaria mercenaria fishery as well (reviewed in Gobler et al. 2005).

Aureococcus anophagefferens may adversely affect the growth and survival of micro- and mesozooplankton (Caron et al. 1989, 2004, Lonsdale et al. 1996, Sieracki et al. 2004). Microzooplankton (20 to $200 \mu \mathrm{m}$; Sieburth et al. 1978, Omori \& Ikeda 1984) are particularly important in marine food webs as a trophic link between pico$(<2 \mu \mathrm{m})$ and nanoplankton ( 2 to $20 \mu \mathrm{m})$ and mesozooplankton (>200 $\mu \mathrm{m}$; Lonsdale et al. 1996, Kiørboe 1998, Calbet \& Landry 1999, Klein Breteler et al. 1999). During brown tides, feeding selectivity by microzooplankton may result in lower grazing rates on $A$. anophagefferens relative to grazing rates on co-occurring phytoplankton, thereby promoting blooms (Gobler et al. 2002, 2004, Caron et al. 2004, Sieracki et al. 2004). Microzooplankton grazing may contribute to the decline of a bloom (Gobler et al. 2004) during a period when microzooplankton abundances often increase (Calbet et al. 2003). However, the species of microzooplankton that may be responsible for grazing on $A$. anophagefferens have been poorly characterized. Moreover, the effect of grazing by larger zooplankton (mesozooplankton), such as copepods, on phagotrophic protists that might consume A. anophagefferens has not been investigated.

Although blooms of Aureococcus anophagefferens have been reported in the US since 1985, the geographic range of these blooms has changed. In the 1990s, severe blooms ( $>10^{6}$ cells $\mathrm{ml}^{-1}$ ) began to appear further south in the mid-Atlantic region of the US, such as Chincoteague Bay in Maryland and in Virginia, which did not experience blooms in the 1980s (reviewed in Gobler et al. 2005). Concomitantly, blooms ceased in more northern regions of its initial range, such as in Rhode Island and the Peconic Estuary of Long Island, New York. Physical dispersal of cells may account for blooms in new regions, but the factors influencing the abatement of blooms from estuaries are not clear. Analysis of physical (temperature, salinity, light) and chemical (organic and inorganic nutrients) parameters suggests that the physiochemical conditions of these latter systems have not changed since blooms ceased to occur (Taylor et al. 2006).

We hypothesize that changes in the zooplankton community structure and/or grazing activity during the years following the initial outbreak of brown tides in the mid-1980s has influenced the geographical distribution of blooms caused by Aureococcus anophagefferens in US estuaries. Prior research demonstrating the ability of zooplankton communities to adapt to toxic algae would support such a hypothesis (Hairston et al. 2001, Colin \& Dam 2002). Colin \& Dam (2002) studied the latitudinal differences in copepods exposed to blooms of highly toxic strains of the dino- flagellate Alexandrium sp. (northern range; Maine/ Massachusetts) compared to those exposed to less frequent and less toxic blooms (southern range; Connecticut/New Jersey). They found that copepods which were frequently exposed to blooms were able to graze highly toxic strains of Alexandrium sp., while copepods which rarely experienced blooms could not. A similar degree of adaptation in zooplankton communities exposed to $A$. anophagefferens might alter brown tide dynamics in formerly bloom-prone estuaries. In the present study, we tested this hypothesis by conducting field research within the south shore estuary system of Long Island in the spring and summer of 2002, 2003, and 2004. Chincoteague Bay, Maryland, was also studied in the summer of 2004, during an intense brown tide. Our objectives were to estimate the grazing effect of different size classes of zooplankton (nano-, micro-, and meso-) on A. anophagefferens and co-occurring phytoplankton, and to determine the diversity and abundance of protists and mesozooplankton in estuaries that experience frequent and intense brown tides, as well as in bays where blooms are sporadic and/or absent.

\section{MATERIALS AND METHODS}

Field sampling and seawater incubation experiments were conducted during the spring (May) and summer (June, July, and August) of 2002, 2003, and 2004. Field sampling was conducted in Quantuck Bay $\left(\mathrm{NY}, 40.81^{\circ} \mathrm{N}, 72.62^{\circ} \mathrm{W}\right)$, which is located in the south shore estuary system of Long Island and has experienced brown tides for nearly two decades (Fig. 1; reviewed in Gobler et al. 2005). Public Landing (MD, $38.15^{\circ} \mathrm{N}, 75.29^{\circ} \mathrm{W}$ ) in Chincoteague Bay was sampled in the summer of 2004, during an intense brown tide event (Fig. 1).

Light penetration of the water column was characterized for each sampling date using a Secchi disk. Temperature, salinity, and dissolved oxygen concentrations were measured using a Quanta probe from Hydrolab. Duplicate micro-/mesoplankton (>64 $\mu \mathrm{m})$ samples were collected by concentrating 401 of subsurface ( $0.5 \mathrm{~m}$ depth) seawater and preserving it in $5 \%$ buffered formalin. Additionally, 201 of water was collected just below the surface without bubbling in Nalgene polycarbonate carboys for further phytoplankton and zooplankton quantification, as described below. Carboys, experimental bottles, Nitex mesh filters, filter cartridges, and tubing were stored in $10 \% \mathrm{HCl}$ between sampling dates and were rinsed liberally with distilled-deionized water before use.

Water samples were kept cool and in the dark during transport to the laboratory, where they were processed 


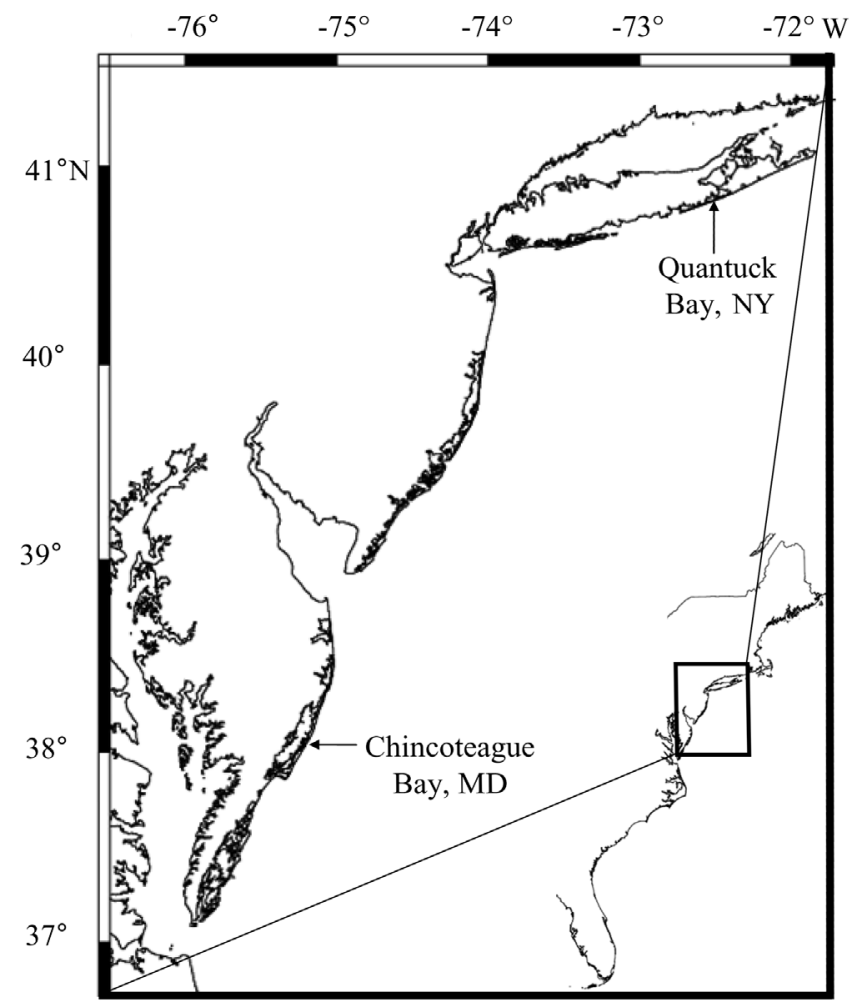

Fig. 1. Locations of the 2 study sites on the eastern seaboard of the US: Quantuck Bay, New York (NY), and Public Landing, in Chincoteague Bay, Maryland (MD)

immediately. Subsamples were removed for sizefractionated chlorophyll a (chl a) analysis, Aureococcus anophagefferens quantification, flow cytometry, transmission electron microscopy, microplankton enumeration, and nutrient analyses. Phytoplankton biomass in whole (unfractionated) seawater was obtained from subsamples collected by filtering 60 to $120 \mathrm{ml}$ of seawater directly onto glass fiber filters (GF/F, $25 \mathrm{~mm}$, nominal pore size $=0.7 \mu \mathrm{m}$ ). Chlorophyll in the $<5 \mu \mathrm{m}$ size range was obtained from 60 to $120 \mathrm{ml}$ subsamples filtered through $\mathrm{a}<5 \mu \mathrm{m}$ pore size polycarbonate filter, and then onto a GF/F filter. Triplicate chlorophyll subsamples were analyzed by standard fluorometric methods (Parsons et al. 1984).

Triplicate $4.5 \mathrm{ml}$ seawater samples for the enumeration of Aureococcus anophagefferens and for flow cytometric quantification were preserved in $1 \%$ glutaraldehyde. Flow cytometry samples were flash frozen in liquid nitrogen and stored at $-80^{\circ} \mathrm{C}$. $A$. anophagefferens sampled were kept at $4^{\circ} \mathrm{C}$ and densities were determined using an ELISA-based monoclonal antibody labeling technique (Caron et al. 2003). This method estimates abundances of $A$. anophagefferens in natural samples to a lower threshold concen- tration of approximately $5 \times 10^{3}$ cells $\mathrm{ml}^{-1}$. Densities of phycoerythrin-containing picocyanobacteria and photosynthetic picoeukaryotes were determined using a FACScaliber (BD) flow cytometer to determine fluorescence patterns and particle size from forward angle light scatter for samples collected in 2003 and 2004.

Transmission electron microscopy (TEM) was used to identify dominant species of nanoplankton (most were between 2.0 and $16 \mu \mathrm{m}$ ) that occurred in the 2003 and 2004 samples. Since June is traditionally the month when brown tides initiate (reviewed in Gobler et al. 2005), we examined all June samples from all sites and years. We also examined all samples from MD. Seawater samples $(180 \mathrm{ml})$ were preserved with $2 \%$ glutaraldehyde in $0.05 \mathrm{M}$ cacodylate solution. Samples were stored at $4^{\circ} \mathrm{C}$. TEM was performed in the Electron Optics Laboratory of Columbia University's Lamont-Doherty Earth Observatory. TEM samples $(200 \mathrm{ml})$ were allowed to settle, and then the overlying supernatant was removed until only $20 \mathrm{ml}$ remained. These samples were resuspended, and each was divided into 2 equal portions. These portions were subsampled, and individual drops were deposited on carbon-reinforced, formvar-coated, copper grids (200 $\mu \mathrm{m}$ mesh) and air-dried at room temperature $\left(25^{\circ} \mathrm{C}\right)$. The grids were shadow-coated with a carbonplatinum source at approximately a $45^{\circ}$ angle using a Denton High Vacuum Evaporator. The shadow-coated particulates were examined in a Philips 201 transmission electron microscope. Transmission electron micrographs were prepared using $35 \mathrm{~mm}$ fine-grain-positive Kodak film. The films were scanned digitally using a Polaroid high-resolution scanner to produce digital images of the TEM micrographs. At least 2 grids were prepared for each sample and systematically examined by scanning each of the grid spaces to obtain the relative abundances of the biota.

Duplicate microplankton samples were analyzed according to Hasle (1978) to identify and quantify the major taxonomic categories of microzooplankton and phytoplankton present in the water column during 2003 and 2004. Seawater samples $(180 \mathrm{ml})$ were preserved with acid Lugol's solution (final concentration $10 \%$ ) and counted using an inverted microscope. The duplicate mesoplankton (>64 $\mu \mathrm{m})$ samples that were generated in the field during 2003 and 2004 were counted on a dissecting microscope. Organisms were identified to the major taxonomic category and abundance established. A minimum of 200 organisms or 100 grids (microplankton enumerations) were counted per sample (Omori \& Ikeda 1984).

Dissolved organic and inorganic nutrients were collected in duplicate from filtered seawater prepared using a low-pressure, peristaltic pumping system equipped with an acid-cleaned polypropylene filter 
capsule $(0.2 \mu \mathrm{m}, \mathrm{MSI})$ and acid-washed Teflon tubing (Gobler \& Sañudo-Wilhelmy 2001). Filtered seawater $(\sim 200 \mathrm{ml})$ was collected and frozen. Inorganic nutrients were analyzed by standard spectrophotometric methods (Newell et al. 1967, Jones 1984, Parsons et al. 1984). Total dissolved nitrogen was determined using the persulfate oxidation method according to Valderama (1981), and dissolved organic nitrogen was determined by subtracting dissolved inorganic nitrogen (nitrate, nitrite, ammonium) concentrations from total dissolved nitrogen levels.

For incubation experiments, $120 \mathrm{l}$ of seawater was collected and transported back to the laboratory. Treatments were prepared in triplicate in 1.21 polycarbonate bottles. Treatments included microzooplankton grazing/dilution experiments (Landry \& Hassett 1982, Landry et al. 1995), predator-exclusion experiments, and copepod-addition experiments (Lonsdale et al. 1996, Calbet \& Landry 1999). Incubations were conducted for $24 \mathrm{~h}$.

The microzooplankton-grazing/seawater-dilution experiments were performed to determine the effect of zooplankton grazing on algal mortality. These experiments involved 4 treatments $(100,70,40$, and $15 \%$ whole seawater) each performed in triplicate. Whole seawater was diluted with filtered seawater made using an in-line $0.2 \mu \mathrm{m}$ cartridge filter. Levels of dissolved organic and inorganic nutrients in this filtered seawater did not differ from levels measured using combusted $\left(2 \mathrm{~h}\right.$ at $\left.450^{\circ} \mathrm{C}\right)$ glass fiber filters. An additional bottle was filled with $0.2 \mu \mathrm{m}$ filtered seawater to verify that the $0.2 \mu \mathrm{m}$ filters removed all phytoplankton. All bottles were amended with nitrate $(20 \mu \mathrm{M}$ final concentration) and orthophosphate $(1.25 \mu \mathrm{M}$ final concentration) in order to assure nutrient-replete growth of phytoplankton (Landry et al. 1995). An additional triplicate set of experimental bottles of whole seawater without nutrients was used to examine the effect of nutrient additions (Landry et al. 1995).

Predator-exclusion experiments (Calbet \& Landry 1999) were conducted to elucidate the effects of different size classes of zooplankton on lower trophic levels. Removing larger size classes presumably reduces the grazing pressure on plankton in the next-smallest size class. Changes in the net growth rate of the latter size class provides insight into the structure of the planktonic food web. Seawater was filtered by in-line gravity filtration through Nitex mesh to remove different size classes of plankton. Treatments consisted of whole (unfiltered) seawater, and seawater filtered through 10 and $5 \mu \mathrm{m}$ mesh. In MD in 2004, the same experiments also included a $<3 \mu \mathrm{m}$ size fraction made with cartridge filters. All bottles were amended with nutrients as described for the dilution experiments. Filtrate was collected from all mesh sizes for triplicate chl a analy- sis. Filtrate from the $<3 \mu \mathrm{m}$ size fraction was also preserved and analyzed for the abundance of Aureococcus anophagefferens in MD.

Mesozooplankton-addition experiments were performed according to Calbet \& Landry (1999) to elucidate the effect of mesozooplankton grazing on plankton communities. Mesozooplankton were concentrated from ambient seawater using $200 \mu \mathrm{m}$ netting, and added to 5 bottles $(1.2 \mathrm{l}$ each) that were filled with $200 \mu \mathrm{m}$ filtered seawater. The specific volume of zooplankton concentrate added depended on the concentration to be achieved, which was 4 -fold the natural assemblage in the summer of 2003 and 8-fold in the summer of 2004. Organisms on the mesh were carefully transferred to the filtered seawater beaker using $200 \mu \mathrm{m}$ filtered water. This solution was then gently mixed, and the volume required to attain each level of enrichment was transferred back into each experimental bottle, with care being taken to mix between transfers. Two bottles were immediately sacrificed following the experimental setup to obtain $T_{0}$ samples for analysis of mesozooplankton and microplankton abundance, and triplicate chl $a$ analyses. All bottles used for the incubations were amended with nutrients as described above.

All experimental bottles were incubated for $24 \mathrm{~h}$ just below the surface of Old Fort Pond at the Southampton College Marine Station, NY, USA (Gobler et al. 2002, 2004). The bottles were covered during incubation with 1 layer of neutral-density screening if it was cloudy (33\% reduction in light) and 2 layers if it was sunny ( $66 \%$ reduction), mimicking the light intensity at approximately $1 \mathrm{~m}$ depth (Gobler et al. 2002, 2004). Samples for chl a analysis, Aureococcus anophagefferens abundance, and flow cytometric analysis were obtained from each of the experimental bottles at the end of the incubations.

Net growth rates of Aureococcus anophagefferens, picocyanobacteria (i.e. Synechococcus sp.), photosynthetic picoeukaryotes, and the total phytoplankton community (TPC) were determined using initial and final cell densities or chl a concentrations. Growth rates were calculated using the formula: $k=[\ln$ $\left.\left(B_{t} / B_{0}\right)\right] / t$, where $k$ is the net growth rate, $B_{t}$ is the biomass or cell density at $t=1 \mathrm{~d}, B_{0}$ is the biomass or cell density at $t=0 \mathrm{~d}$, and $t$ is the length of the experiment (Gobler et al. 2002). Net growth rate takes into account the intrinsic growth rate and the mortality rate. In our experiments, changes in net growth rate indicated changes to the mortality rate because the intrinsic growth rate should remain constant among treatments under the nutrient-replete and common light and temperature conditions of our experiments. Mortality rates in the dilution experiments were determined from linear regressions of net (apparent) growth rate versus 
the proportion of whole seawater $(0.15,0.40,0.70,1.0)$. The slope of this regression yielded the mortality rate, which we assumed was predominantly due to microzooplankton grazing, and the $y$-intercept, adjusted for nutrient addition, was equivalent to the theoretical growth rate in the absence of predators (Landry \& Hassett 1982, Landry et al. 1995). Three-point regressions of dilution curves during this study did not indicate saturation of grazing during experiments (Gallegos 1989).

\section{RESULTS}

\section{Dynamics of plankton populations}

Chincoteague Bay experienced an intense brown tide during the summer of 2004. Aureococcus anophagefferens abundances in MD were highest on 17 June

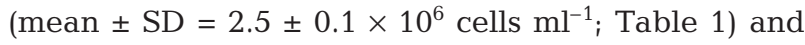
remained at bloom densities throughout the summer $\left(>5 \times 10^{4}\right.$ cells $\mathrm{ml}^{-1}$; Table 1$)$. A moderate brown tide occurred in Quantuck Bay, NY, during 2002, but not in 2003 or 2004. A. anophagefferens densities during 2002 were highest on 18 June $\left(8.6 \pm 0.36 \times 10^{5}\right.$ cells $\mathrm{ml}^{-1}$ ) and then declined throughout the rest of the sampling season (Table 1). Densities in NY during 2003 and 2004 were much lower, averaging $2.0 \pm 0.6 \times 10^{4}$ cells ml $\mathrm{ml}^{-1}$ in 2003 and $1.7 \pm 0.2 \times 10^{4}$ cells ml $\mathrm{ml}^{-1}$ in 2004 $($ mean $\pm \mathrm{SE}$, Table 1).

Chl a concentrations were similar among all years and sites during this study, with levels ranging from 5 to $25 \mathrm{\mu g} \mathrm{l}^{-1}$ (Fig. 2). The dominant size class of phytoplankton in MD was $<5 \mu \mathrm{m}$ for the duration of sampling (seasonal mean $\pm \mathrm{SE}=18 \pm 2.8 \mu \mathrm{g} \mathrm{l}^{-1}$ was $<5 \mu \mathrm{m}$ ). during mid-June, July, and August were significantly higher than those in NY in 2003 and 2004 (Tukey, p < 0.05; parameter not measured for NY 2002; Table 1). Maximal abundances of Synechococcus spp. in MD were also substantially greater than those in NY during 2003 and 2004 (Table 1).

Electron microscopic examination of autotrophic nanoplankton indicated that, although there were similarities in community composition between the 2 sampling locations, the dominant species differed between MD and NY (Table 2). The most abundant nanoplankton in MD were the centric diatom Thalassiosira proschkinae (mean $\pm \mathrm{SE}=15 \pm 4.6 \%$ of total) and biflagellates $(20 \pm 4.6 \%$ of total counted; Table 2$)$. In NY, the dominant nanoplankter in June during 2003 and 2004 was the centric diatom Cyclotella choctawhatcheeana (2003: June mean $\pm \mathrm{SE}=29 \pm 6.6 \%$ of total; $2004: 42 \pm$ $13 \%$ of total), a species which was rare in MD (6.0 \pm $3.0 \%)$. In 2003 , biflagellates $(16 \pm 4.4 \%$ of total $)$ and pennate diatoms $(16 \pm 2.2 \%$ of total $)$ were also abundant in NY, and in 2004 the centric diatom Skeletonema costatum represented $15 \pm 4.5 \%$ of the total counted.

Among autotrophic microplankton, there was an abundant, co-occurring, subdominant assemblage of microplanktonic pennate diatoms $\left(>1.7 \times 10^{4} \mathrm{l}^{-1}\right)$ and dinoflagellates $\left(>7.8 \times 10^{3} \mathrm{l}^{-1}\right)$ during the peak of the brown tide in MD (Fig. 3C). These groups were also present in NY, but at lower maximal densities (pennate diatoms $\sim 7.9 \times 10^{3} \mathrm{l}^{-1}$; dinoflagellates $\sim 1.1 \times 10^{3} \mathrm{l}^{-1}$; Fig. 3B). Photosynthetic microflagellates were always present at moderate densities during both years in NY (2003: mean $\pm \mathrm{SE}=5.3 \pm 2.2 \times 10^{3}$ cells ml $^{-1} ; 2004: 2.1$ $\pm 1.2 \times 10^{4}$ cells ml $^{-1}$; Fig. 3 ), but were not apparent in

In contrast, concentrations of chl a $<5 \mu \mathrm{m}$ in NY during 2002, 2003, and 2004 were less than half of the levels found in MD (2002: seasonal mean \pm $\mathrm{SE}=7.2 \pm 1.9 \mu \mathrm{g} \mathrm{l}^{-1}$ was $<5 \mu \mathrm{m} ; 2003$ : $8.1 \pm 2.0 \mu \mathrm{g} \mathrm{l}^{-1}$ was $<5 \mu \mathrm{m} ; 2004: 7.3 \pm$ $2.0 \mu \mathrm{g}^{-1}$ was $\left.<5 \mu \mathrm{m}\right)$.

Densities of autotrophic picoplankton populations paralleled trends observed in size-fractionated chl a. In MD in 2004, after the peak of the brown tide, densities of other picoplanktonic species remained high (Table 1). A maximum in the density of Synechococcus spp. occurred in MD on 28 June $\left(1.3 \pm 0.15 \times 10^{4}\right.$ cells $\mathrm{ml}^{-1}$ ), and the maximal density of photosynthetic picoeukaryotes occurred on 13 July $\left(2.8 \pm 0.07 \times 10^{6}\right.$ cells $\mathrm{ml}^{-1}$; Table 1). Densities of photosynthetic picoeukaryotes in $\mathrm{MD}$

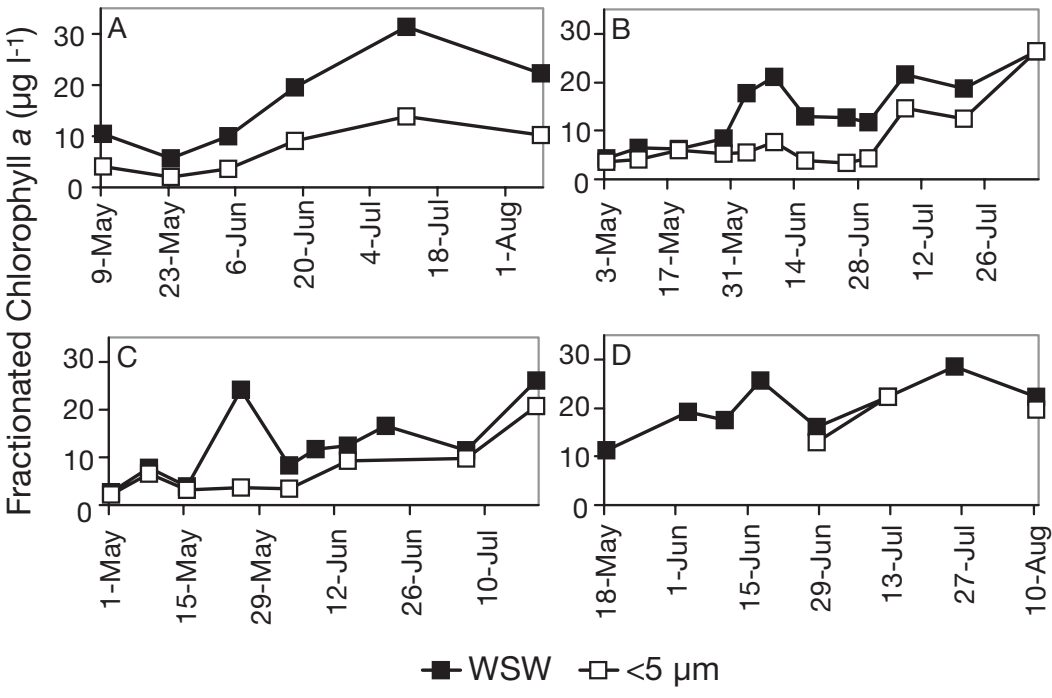

Fig. 2. Time series of total (whole seawater, WSW) and $<5 \mu \mathrm{m}$ chlorophyll $a$ in (A) Quantuck Bay, NY, in 2002, (B) Quantuck Bay, NY, in 2003, (C) Quantuck Bay, NY, in 2004, and (D) Public Landing, MD, during the bloom in 2004 
samples from MD until the last sampling date. Microflagellates in NY were almost exclusively euglenoids, with occasional silicoflagellates present.

Abundances of smaller grazers $(<64 \mu \mathrm{m})$ differed among sites during this study (Fig. 3, Table 2). Elevated densities of the heterotroph Paulinella ovalis $(<5 \mu \mathrm{m}, 23 \pm 7.1 \%$ of total counted by electron micro- scopy) were found in MD, while this species was almost absent in NY during 2003 and 2004 (Table 2). NY hosted moderate densities of rotifers through the month of May $(>40 \mu \mathrm{m}, 2003$ : monthly mean $\pm \mathrm{SE}=$ $43 \pm 25 \mathrm{l}^{-1}$; 2004: $61 \pm 54 \mathrm{l}^{-1}$; Fig. 4A,B), while these grazers were not present in any of the samples from MD during the months sampled there (June to

Table 1. In situ conditions at each sampling site during the present study. Temperature $\left(T,{ }^{\circ} \mathrm{C}\right)$, salinity $(\mathrm{S}$, psu), and Secchi depth $(\mathrm{m})$ are shown. Mean densities (cells $\mathrm{ml}^{-1}, \pm \mathrm{SD}$ ) of triplicate measurements of Aureococcus anophagefferens (BT), photosynthetic picoeukaryotes (PEUK), and Synechococcus (SYN) are also shown. All nutrients represent means ( \pm SD) of duplicate measurements

\begin{tabular}{|c|c|c|c|c|c|c|c|c|c|}
\hline & $T$ & $\mathrm{~S}$ & $\begin{array}{l}\text { Secchi } \\
\text { depth }\end{array}$ & $\begin{array}{c}\text { BT } \\
\left(\times 10^{4}\right)\end{array}$ & $\begin{array}{l}\text { PEUK } \\
\left(\times 10^{4}\right)\end{array}$ & $\begin{array}{l}\text { SYN } \\
\left(\times 10^{3}\right)\end{array}$ & $\begin{array}{l}\text { DIN } \\
(\mu \mathrm{M})\end{array}$ & $\begin{array}{c}\text { DIP } \\
(\mu \mathrm{M})\end{array}$ & $\begin{array}{l}\text { DON } \\
(\mu \mathrm{M})\end{array}$ \\
\hline \multicolumn{10}{|l|}{ NY 2002} \\
\hline 19 Apr & 20 & 29 & 1.3 & $1.0 \pm 0.35$ & & & $0.38 \pm 0.15$ & $0.42 \pm 0.21$ & $38 \pm 1.1$ \\
\hline 09 May & 16 & 30 & 1.2 & $3.2 \pm 0.16$ & & & $0.59 \pm 0.42$ & $0.35 \pm 0.21$ & $23 \pm 5.4$ \\
\hline 23 May & 16 & 28 & 1.4 & $3.7 \pm 0.33$ & & & $1.2 \pm 0.89$ & $0.11 \pm 0.03$ & $31 \pm 1.5$ \\
\hline 04 Jun & 20 & 29 & 1.5 & $6.8 \pm 0.19$ & & & $1.2 \pm 0.70$ & $0.26 \pm 0.04$ & $37 \pm 2.0$ \\
\hline 18 Jun & 21 & 26 & 0.8 & $86 \pm 3.6$ & & & $1.1 \pm 0.65$ & $0.28 \pm 0.10$ & $43 \pm 0.80$ \\
\hline $11 \mathrm{Jul}$ & 24 & 30 & 0.7 & $11 \pm 0.19$ & & & $2.6 \pm 1.2$ & $0.31 \pm 0.10$ & $42 \pm 0.92$ \\
\hline 08 Aug & 24 & 29 & 0.5 & $1.0 \pm 0.06$ & & & $0.19 \pm 0.20$ & $1.0 \pm 0.12$ & $55 \pm 7.3$ \\
\hline Mean \pm SE & $20 \pm 1$ & $29 \pm 1$ & $1.0 \pm 0.1$ & $16 \pm 12$ & & & $1.0 \pm 0.30$ & $0.40 \pm 0.11$ & $39 \pm 3.7$ \\
\hline \multicolumn{10}{|l|}{ NY 2003} \\
\hline 03 May & 15 & 27 & 1.8 & $1.5 \pm 0.24$ & $35 \pm 2.7$ & $0.91 \pm 0.32$ & $0.84 \pm 0.29$ & $0.51 \pm 0.29$ & $15 \pm 5.2$ \\
\hline 10 May & 15 & 26 & 1.1 & $7.9 \pm 0.48$ & $8.4 \pm 2.9$ & $2.0 \pm 0.71$ & $0.36 \pm 0.48$ & $0.46 \pm 0.21$ & $21 \pm 4.3$ \\
\hline 19 May & 15 & 28 & 1.6 & $2.1 \pm 0.19$ & $28 \pm 0.16$ & $1.8 \pm 0.58$ & $8.5 \pm 1.3$ & $0.40 \pm 0.09$ & $21 \pm 7.7$ \\
\hline 29 May & 15 & 25 & 1.5 & $1.3 \pm 0.28$ & 13 & 2.5 & $4.7 \pm 0.58$ & $0.34 \pm 0.02$ & $16 \pm 1.1$ \\
\hline 03 Jun & 18 & 24 & 1.4 & $1.1 \pm 0.16$ & $4.0 \pm 0.87$ & $1.5 \pm 0.43$ & $0.88 \pm 0.40$ & $0.25 \pm 0.06$ & $18 \pm 0.34$ \\
\hline 09 Jun & 18 & 21 & 1.3 & $1.0 \pm 0.37$ & $8.6 \pm 0.30$ & $2.4 \pm 1.9$ & $1.5 \pm 0.72$ & $0.44 \pm 0.14$ & $19 \pm 3.3$ \\
\hline 16 Jun & 19 & 25 & 1.3 & $1.2 \pm 0.19$ & $10 \pm 0.37$ & $2.8 \pm 0.29$ & $1.1 \pm 0.16$ & $0.36 \pm 0.03$ & $25 \pm 0.04$ \\
\hline 25 Jun & 24 & 23 & 1.5 & $0.68 \pm 0.20$ & $6.5 \pm 1.2$ & $2.4 \pm 1.0$ & $0.92 \pm 0.20$ & $0.27 \pm 0.06$ & $27 \pm 0.64$ \\
\hline 30 Jun & 25 & 25 & 1.9 & $1.6 \pm 0.33$ & $7.6 \pm 0.01$ & $2.5 \pm 0.13$ & $1.32 \pm 0.14$ & $0.47 \pm 0.08$ & $32 \pm 1.1$ \\
\hline $08 \mathrm{Jul}$ & 29 & 22 & 0.9 & $2.7 \pm 0.13$ & $23 \pm 0.28$ & $0.55 \pm 0.01$ & $0.60 \pm 0.08$ & $0.80 \pm 0.10$ & $36 \pm 0.26$ \\
\hline $21 \mathrm{Jul}$ & 26 & 25 & 1.6 & $1.8 \pm 0.28$ & $27 \pm 0.17$ & $19 \pm 0.05$ & $5.0 \pm 0.73$ & $0.78 \pm 0.04$ & $32 \pm 0.02$ \\
\hline 06 Aug & 27 & 27 & 1.0 & $1.6 \pm 0.16$ & $110 \pm 7.5$ & $170 \pm 8.7$ & $0.39 \pm 0.39$ & $0.19 \pm 0.01$ & $36 \pm 5.8$ \\
\hline Mean \pm SE & $20 \pm 2$ & $25 \pm 1$ & $1.4 \pm 0.1$ & $2.0 \pm 0.55$ & $23 \pm 8.4$ & $17 \pm 14$ & $2.2 \pm 0.73$ & $0.44 \pm 0.05$ & $25 \pm 2.2$ \\
\hline \multicolumn{10}{|l|}{ NY 2004} \\
\hline 01 May & 15 & 25 & 1.3 & $1.4 \pm 0.09$ & $17 \pm 2.5$ & $4.1 \pm 1.2$ & $4.5 \pm 0.49$ & $0.30 \pm 0.03$ & $23 \pm 2.4$ \\
\hline 08 May & 16 & 25 & 1.8 & $1.9 \pm 0.54$ & $50 \pm 0.77$ & $2.7 \pm 0.12$ & $0.69 \pm 0.40$ & $0.57 \pm 0.15$ & $26 \pm 1.1$ \\
\hline 15 May & 19 & 23 & 1.3 & $1.4 \pm 0.36$ & 79 & 3.1 & $4.7 \pm 0.48$ & $0.50 \pm 0.26$ & $26 \pm 2.7$ \\
\hline 25 May & 19 & 27 & 1.6 & $1.4 \pm 0.09$ & $4.9 \pm 0.33$ & $1.1 \pm 0.93$ & $0.05 \pm 0.04$ & $0.16 \pm 0.22$ & $24 \pm 4.8$ \\
\hline 03 Jun & 21 & 26 & 1.1 & $2.1 \pm 0.32$ & $7.7 \pm 0.14$ & $2.2 \pm 0.69$ & $3.5 \pm 1.6$ & $0.20 \pm 0.11$ & $22 \pm 1.2$ \\
\hline 08 Jun & 20 & 28 & 1.8 & $2.1 \pm 0.17$ & $52 \pm 1.4$ & $4.6 \pm 0.800$ & $4.2 \pm 0.67$ & $0.45 \pm 0.25$ & $32 \pm 5.8$ \\
\hline 14 Jun & 20 & 28 & 1.4 & $1.6 \pm 0.14$ & $54 \pm 4.1$ & $5.0 \pm 1.4$ & $3.4 \pm 0.11$ & $1.1 \pm 0.04$ & $25 \pm 6.2$ \\
\hline 21 Jun & 22 & 27 & 1.3 & $2.6 \pm 0.14$ & $31 \pm 0.79$ & $14 \pm 0.50$ & $3.8 \pm 0.24$ & $0.61 \pm 0.11$ & $27 \pm 2.4$ \\
\hline $06 \mathrm{Jul}$ & 25 & 28 & 1.5 & $0.98 \pm 0.14$ & $19 \pm 0.61$ & $77 \pm 4.7$ & $9.4 \pm 0.51$ & $0.54 \pm 0.14$ & $34 \pm 4.8$ \\
\hline $19 \mathrm{Jul}$ & 24 & 28 & 1.1 & $1.9 \pm 0.13$ & $58 \pm 3.2$ & $250 \pm 6.3$ & $0.62 \pm 0.08$ & $0.88 \pm 0.09$ & $28 \pm 0.40$ \\
\hline Mean \pm SE & $20 \pm 1$ & $27 \pm 1$ & $1.4 \pm 0.1$ & $1.7 \pm 0.15$ & $37 \pm 7.8$ & $36 \pm 25$ & $3.5 \pm 0.86$ & $0.53 \pm 0.09$ & $27 \pm 1.2$ \\
\hline \multicolumn{10}{|l|}{ MD 2004} \\
\hline 19 May & 25 & 23 & & 31 & & & & & \\
\hline 03 Jun & 25 & 24 & & 45 & & & & & \\
\hline 09 Jun & 26 & 24 & & 51 & & & & & \\
\hline 17 Jun & 25 & 28 & 0.5 & $250 \pm 8.9$ & $180 \pm 6.8$ & $75 \pm 3.1$ & $0.96 \pm 0.16$ & $1.4 \pm 0.04$ & $34 \pm 3.3$ \\
\hline 28 Jun & 24 & 30 & 0.7 & $59 \pm 3.8$ & $170 \pm 8.5$ & $130 \pm 15$ & $3.2 \pm 0.05$ & $1.2 \pm 0.35$ & $56 \pm 0.65$ \\
\hline $13 \mathrm{Jul}$ & 26 & 31 & 0.4 & $6.7 \pm 1.2$ & $280 \pm 7.0$ & $84 \pm 2.7$ & $1.1 \pm 0.50$ & $1.1 \pm 0.20$ & $52 \pm 8.4$ \\
\hline 25 Jul & & & & $5.2 \pm 0.21$ & $220 \pm 41$ & $65 \pm 7.4$ & & & \\
\hline 10 Aug & 24 & 27 & 0.5 & $8.4 \pm 0.41$ & $83 \pm 6.8$ & $96 \pm 8.7$ & $0.69 \pm 0.44$ & $1.5 \pm 0.13$ & $53 \pm 3.5$ \\
\hline Mean \pm SE & $25 \pm 0$ & $29 \pm 1$ & $0.5 \pm 0.1$ & $57 \pm 29$ & $190 \pm 32$ & $90 \pm 11$ & $1.5 \pm 0.59$ & $1.3 \pm 0.11$ & $49 \pm 5.0$ \\
\hline
\end{tabular}




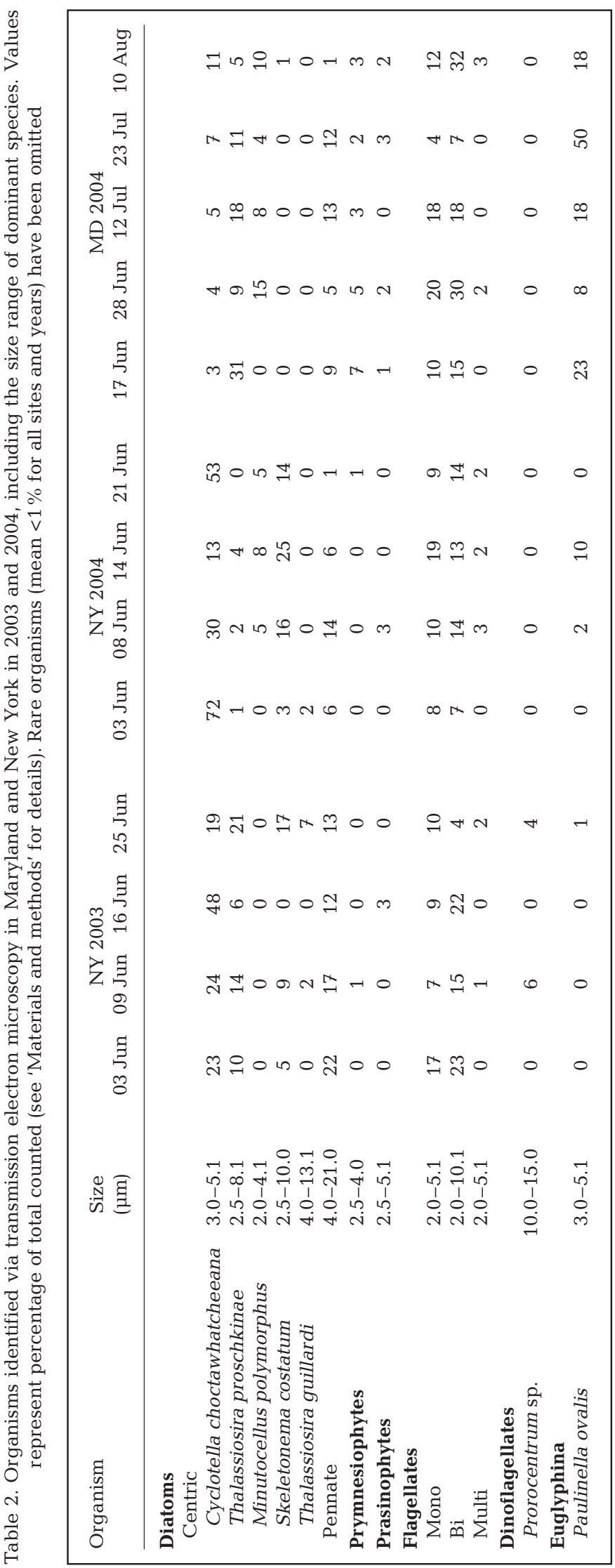

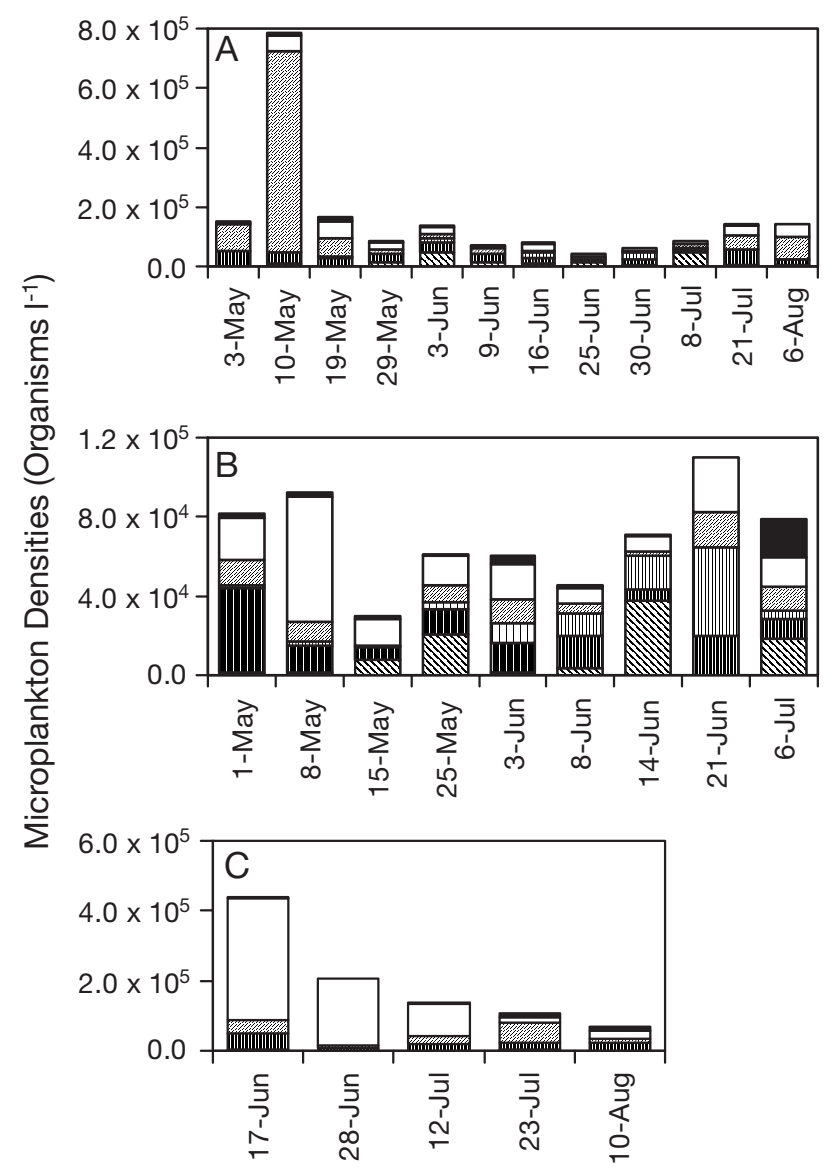

Fig. 3. Field microplankton mean densities on each sampling date in (A) NY in 2003, (B) NY in 2004, and (C) MD in 2004. Relative SD of duplicated counts were $<20 \%$ for all groups enumerated

August). Non-loricate ciliates were the most abundant microzooplankton at both locations $\left(2.2 \pm 0.7 \times 10^{4} \mathrm{l}^{-1}\right.$ and $2.0 \pm 0.5 \times 10^{4} 1^{-1}$ in NY and MD, respectively, in 2004; Fig. 3B,C). The total microzooplankton densities (20 to $200 \mu \mathrm{m}$ ) were not significantly different between sites or years (Fig. 3).

Densities of most groups of larger grazers (>64 $\mu \mathrm{m})$ in NY (2003 and 2004) and MD were similar through the June to August sampling periods (Fig. 4). Interestingly, abundances and diversity of mesoplankton in MD were minimal during the maximum abundance of the brown tide (Fig. 4C, Table 1). Copepod nauplii and polychaete larvae were consistently the most abundant mesoplanktonic organisms in MD and NY during 2003 and 2004 (Fig. 4). The only notable differences among mesozooplankton densities were those of polychaete 


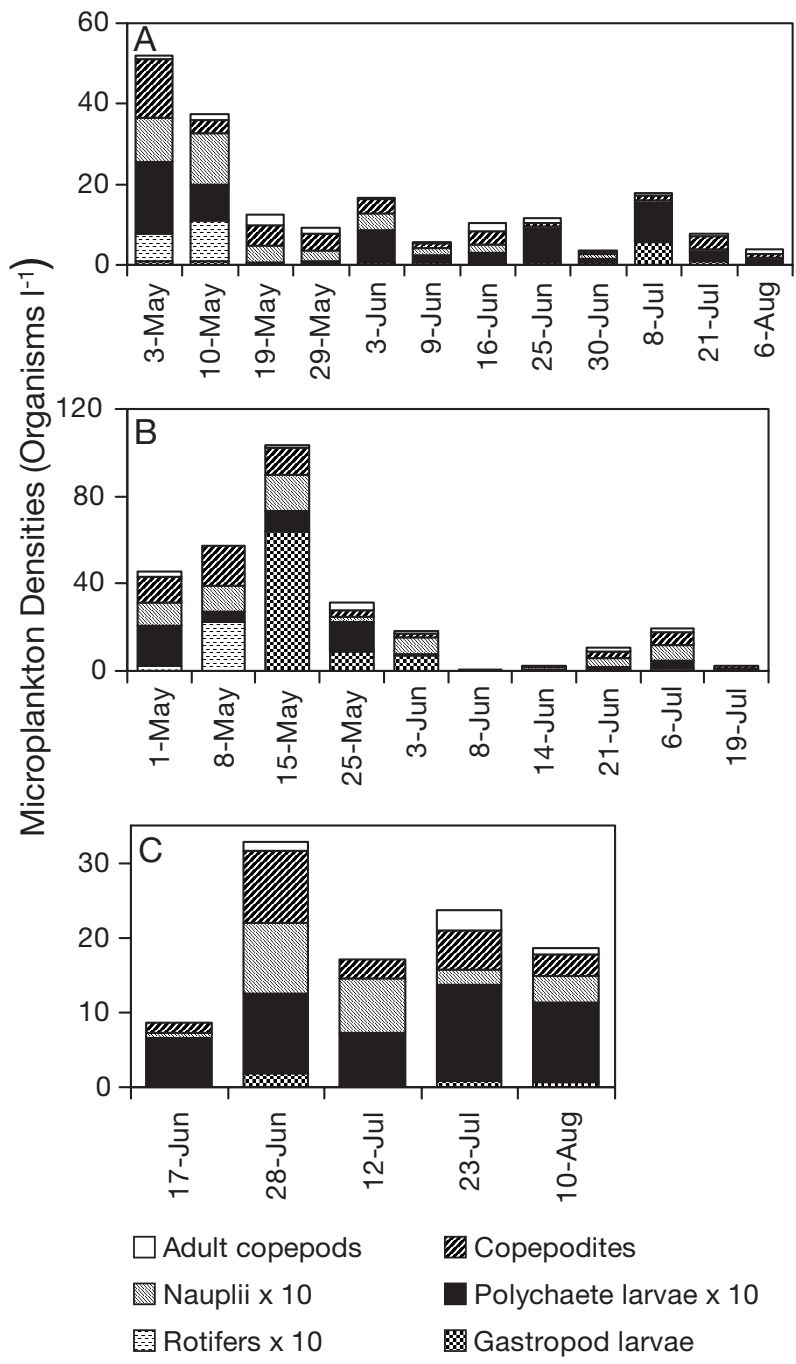

Fig. 4. Field mesoplankton mean densities on each sampling date in (A) NY in 2003, (B) NY in 2004, and (C) MD in 2004. Nauplii, polychaete larvae, and rotifer densities were 10 -fold higher than those displayed. Relative SD of duplicated counts were $<20 \%$ for all groups enumerated

larvae, which were 5-fold lower in MD (9.6 \pm 1.2 ind. $\left.\mathrm{l}^{-1}\right)$ than in NY (2003: $52 \pm 16$ ind. $\mathrm{l}^{-1} ; 2004: 52 \pm 20$ ind. $\mathrm{l}^{-1}$; Fig. 4).

Physical and chemical characteristics of MD and NY during the study did not differ appreciably from previously published reports of brown tides in US Atlantic estuaries (Table 1; reviewed in Gobler et al. 2005). There were no statistically significant differences between sites and years in temperature, salinity, dissolved inorganic nitrogen, or dissolved silicate from late June through early August (Tukey, p < 0.05; Table 1). Nutrient levels within the bays were consistent with previously published reports (reviewed in Gobler et al. 2005), with significantly higher dissolved organic nitrogen at sites hosting blooms (MD and NY
2002) compared to the non-bloom bays (Tukey, p < 0.05, NY 2003 and 2004; Table 1). MD also had significantly higher dissolved inorganic phosphorous through mid-June, July, and August compared to NY during all 3 yr (Tukey, p < 0.05; Table 1).

\section{Experimental results}

Mesozooplankton-addition experiments

The impact of enhanced abundances of mesozooplankton $(>200 \mu \mathrm{m})$ on the net growth rates of Aureococcus anophagefferens and other picophytoplankton differed between bloom and non-bloom sites and among dates. Additions of zooplankton significantly reduced net growth rates of $A$. anophagefferens, compared to the control ( $t$-test, $\mathrm{p}<0.05$ ), in NY during the latter half of the sampling season (late June through July) during both 2003 (e.g. 30 June: control growth rate $\pm \mathrm{SD}=0.27 \pm 0.05$; treatment $=0.01 \pm 0.08$ ) and 2004 (e.g. 22 June: control $=-0.19 \pm 0.15$; treatment $=$ $-0.73 \pm 0.19 ;$ Fig. 5). In NY, photosynthetic picoeukaryotes and Synechococcus spp. were significantly affected by the addition of mesozooplankton only during the last experiment of each year (21 July 2003 and 19 July 2004; Fig. 5). Net growth rates of picoeukaryotes (PEUK) and Synechococcus (SYN) spp. during 2003 were significantly reduced (PEUK: control = $-0.30 \pm 0.09 ;$ treatment $=-0.81 \pm 0.17 ;$ SYN: control $=$ $-0.64 \pm 0.07$; treatment $=-1.1 \pm 0.0$ ), whereas in 2004 net growth rates were significantly increased by the addition of mesozooplankton (PEUK: control $=-0.02 \pm$ 0.07 ; treatment $=0.24 \pm 0.07 ;$ SYN: control $=0.26 \pm$ 0.08 ; treatment $=0.49 \pm 0.07$; Fig. 5). Photosynthetic picoeukaryote and Synechococcus spp. net growth rates in $\mathrm{MD}$ were significantly reduced in all but 1 experiment (28 June; Fig. 5). A. anophagefferens abundance in MD was not significantly affected by mesozooplankton enrichment.

\section{Predator-exclusion experiments}

Analyses of the net growth rates among size classes within the predator-exclusion experiments suggested that there were multiple trophic levels within smaller size classes $(<20 \mu \mathrm{m})$ of the plankton assemblage. In general, net growth rates of the TPC increased as smaller size fractions of the water were incubated (Fig. 6). Net growth rates of Aureococcus anophagefferens responded similarly. The important significant changes in the net growth rate of the brown tide alga in the MD samples occurred between the $<10$ and $<5 \mu \mathrm{m}$ and the $<5$ and $<3 \mu \mathrm{m}$ size fractions. There was 


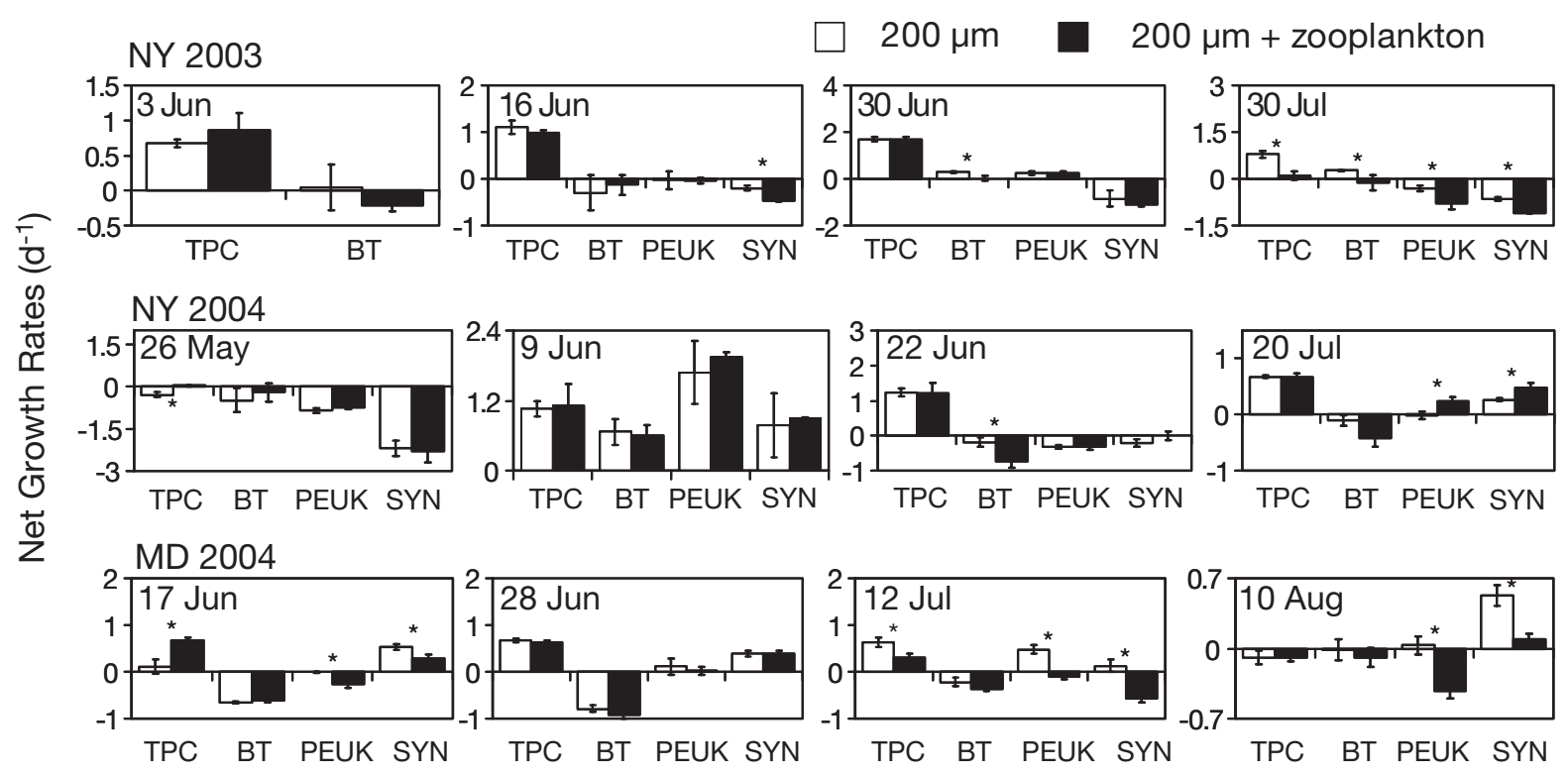

Fig. 5. Mean net growth rates $\left(\mathrm{d}^{-1}, \pm \mathrm{SD}\right)$ of triplicate measurements of the total phytoplankton community (TPC), Aureococcus anophagefferens (BT), photosynthetic picoeukaryotes (PEUK), and Synechococcus (SYN) with and without concentrated mesozooplankton added in NY in 2003 and 2004 and MD in 2004. *: significant difference between control and treatment (Tukey test, $\mathrm{p}<0.05$ )

a significant increase in $A$. anophagefferens net growth rates between the $<5$ and $<3 \mu \mathrm{m}$ size fractions in 3 of 4 experiments (28 June, $<5 \mu \mathrm{m}$ : growth rate \pm $\mathrm{SD}=0.15 \pm 0.08 ;<3 \mu \mathrm{m}: 0.83 \pm 0.05 ; 12$ July, $<5 \mu \mathrm{m}$ : $-0.28 \pm 0.01 ;<3 \mu \mathrm{m}: 0.52 \pm 0.22 ; 10$ August,$<5 \mu \mathrm{m}$ : $-0.13 \pm 0.07 ;<3 \mu \mathrm{m}: 1.2 \pm 0.66 ;$ Fig. 6). For A. anophagefferens in NY in 2004, the $<10 \mu \mathrm{m}$ size fraction generally yielded substantially higher net growth rates than the $<5 \mu \mathrm{m}$ size fraction (e.g. 8 June, $<10 \mu \mathrm{m}$ : $0.45 \pm$ $0.15 ;<5 \mu \mathrm{m}:-2.2 \pm 0.86$; Fig. 6). Most experiments in NY during 2003 did not yield a significant effect with the removal of any size class on net growth rates of the brown tide alga (Fig. 6).

\section{Microzooplankton grazing experiments}

Significant rates of microzooplankton grazing on the TPC and various picoplankton assemblages were consistently obtained in both MD and NY throughout the study period, with the exception of the late May/early June date each year in NY (Table 3). Grazing rates on the TPC were comparable between bloom and nonbloom years in NY (2002: $0.90 \pm 0.29 \mathrm{~d}^{-1} ; 2003$ : $0.77 \pm$ $0.11 \mathrm{~d}^{-1} ;$ 2004: $0.80 \pm 0.19 \mathrm{~d}^{-1}$; Table 3), and overall these rates were higher than rates observed for experiments performed in MD $\left(0.41 \pm 0.12 \mathrm{~d}^{-1}\right.$; Table 3$)$.

Microzooplankton grazing rates on Aureococcus anophagefferens varied between sites and years. A significant grazing rate on $A$. anophagefferens in MD was only obtained on the date when the abundance of the brown tide alga was the lowest (12 July, mean mortality rate $\pm \mathrm{SE}=0.64 \pm 0.12 \mathrm{~d}^{-1}$; Table 3 ). When $A$. anophagefferens densities were high enough to be measured during a dilution experiment in NY in 2004 (>20000 cells $\mathrm{ml}^{-1}$ ), grazing rates on A. anophagefferens were higher than those measured in MD on 12 July $\left(\mathrm{NY}\right.$ : mean $\pm \mathrm{SE}=0.80 \pm 0.04 \mathrm{~d}^{-1}$; Table 3$)$. Grazing on A. anophagefferens in 2002 in NY was detected on most dates $\left(0.40 \pm 0.17 \mathrm{~d}^{-1}\right.$; Table 3$)$. This average grazing rate on $A$. anophagefferens in 2002 was lower than the seasonal average in $2004\left(0.80 \pm 0.04 \mathrm{~d}^{-1}\right)$, but higher than that in MD $\left(0.16 \pm 0.16 \mathrm{~d}^{-1}\right.$; Table 3$)$. A. anophagefferens densities were never high enough in NY in 2003 to obtain accurate cell densities in the lowest dilution treatment, and thus mortality rates could not be established from those experiments.

Microzooplankton grazing rates on Aureococcus anophagefferens in MD during the period of the intense brown tide were lower than rates for other picoplankton populations (Table 3). Although significant grazing rates on $A$. anophagefferens in MD were often not measured, there was significant grazing on other picoplankton on almost every date at this site (0.33 to $0.60 \mathrm{~d}^{-1}$, with the exception of 28 June; Table 3). Grazing rates on Synechococcus spp. were higher in NY in 2004 compared to MD when measured toward the end of the sampling season (NY: mean \pm $\mathrm{SE}=1.2 \pm 0.29 \mathrm{~d}^{-1} ; \mathrm{MD}: 0.41 \pm 0.12 \mathrm{~d}^{-1}$; Table 3). For this same time period, however, grazing rates on photosynthetic picoeukaryotes were similar between the 2 sites in 2004 (NY: $0.54 \pm 0.15 \mathrm{~d}^{-1}$; MD: $0.60 \pm$ 


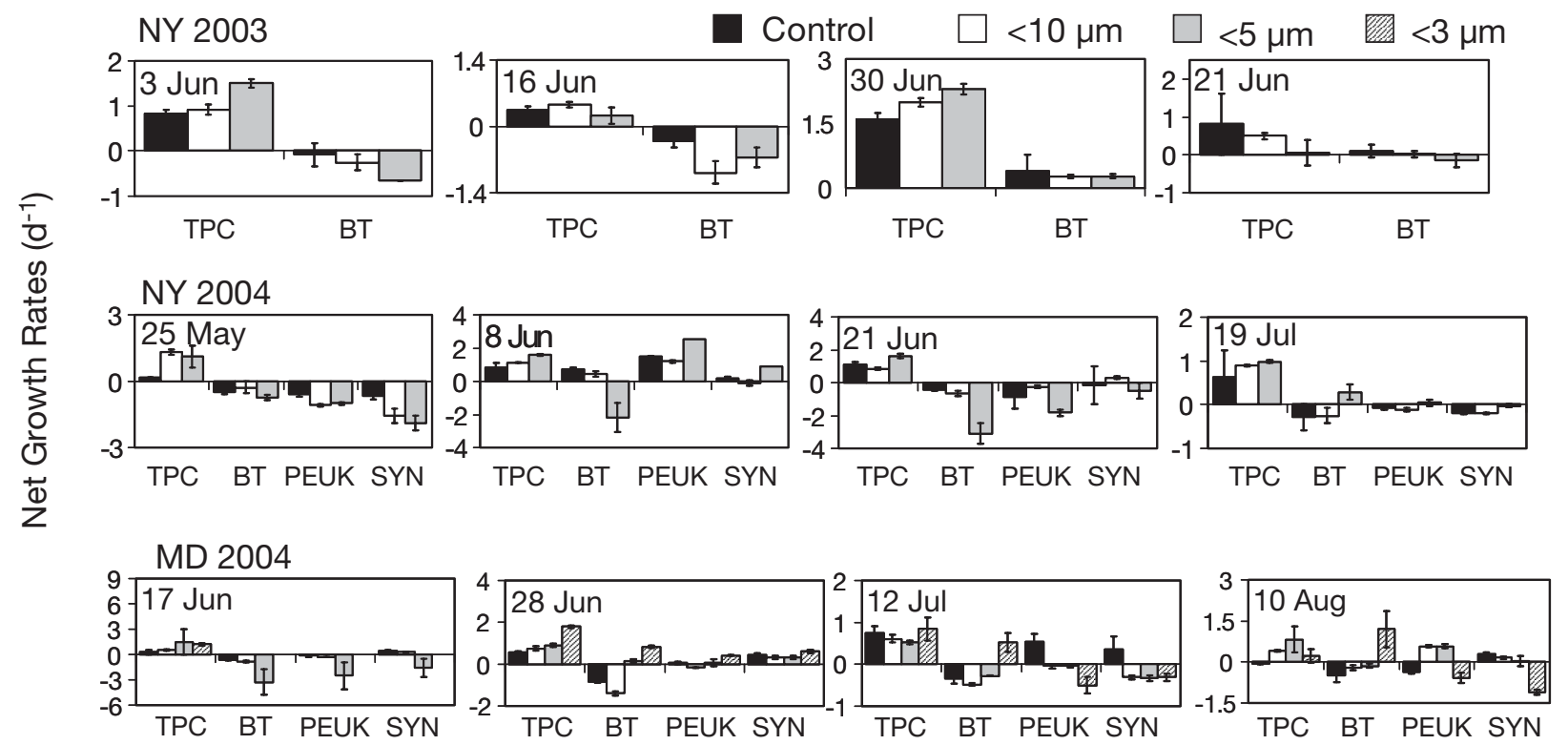

Fig. 6. Predator-exclusion experiments in NY in 2003 and 2004 and MD in 2004. Values are the mean growth rate ( \pm SD) of triplicate measurements within control, $<10 \mu \mathrm{m},<5 \mu \mathrm{m}$, and $<3 \mu \mathrm{m}$ treatments. Abbreviations as in Fig. 5. Note, the NY experiments did not include a $<3 \mu \mathrm{m}$ treatment and the NY 2003 graphs do not include data for PEUK and SYN

$0.16 \mathrm{~d}^{-1}$; Table 3). When measured, the results from these seawater dilution experiments indicated that all populations experienced nutrient limitation for most dates during the sampling season (Table 3).

\section{DISCUSSION}

We compared the response of Aureococcus anophagefferens and co-occurring picoplankton populations to experimental manipulations of zooplankton during bloom and non-bloom conditions. Our results indicated that $A$. anophagefferens experienced reduced grazing pressure during bloom periods compared to other populations, such as Synechococcus spp. and photosynthetic picoeukaryotes, and compared to $A$. anophagefferens populations during nonbloom periods. We also noted differences in the phytoplankton and zooplankton community composition between bloom and non-bloom locations. Below, we discuss how differences in planktonic community structure and grazing may influence the occurrence of brown tides caused by $A$. anophagefferens in US estuaries.

\section{Increases in microzooplankton grazing on Aureococcus anophagefferens}

Microzooplankton grazing rates on the TPC were comparable in NY for all $3 \mathrm{yr}$, but the grazing rate on Aureococcus anophagefferens increased from 2002 to
2004 (Fig. 7). Taken together with the general absence of microzooplankton grazing on $A$. anophagefferens in $\mathrm{MD}$, it appears that there is a gradation in microzooplankton grazing on A. anophagefferens, with little-tono grazing occurring during intense blooms (MD 2004), moderate grazing occurring in bays hosting a short, less intense bloom (NY 2002), and high rates of grazing on $A$. anophagefferens under non-bloom conditions (NY 2004). These observations are consistent with prior research, which has demonstrated that microzooplankton grazing on $A$. anophagefferens can be lower than on other populations during a bloom (Gobler et al. 2002, 2004, Caron et al. 2004). In MD, microzooplankton grazers consumed other phytoplankton at significant rates throughout the sampling period (Table 3), indicating that grazing is not inhibited by the presence of brown tide, but rather that A. anophagefferens is often avoided.

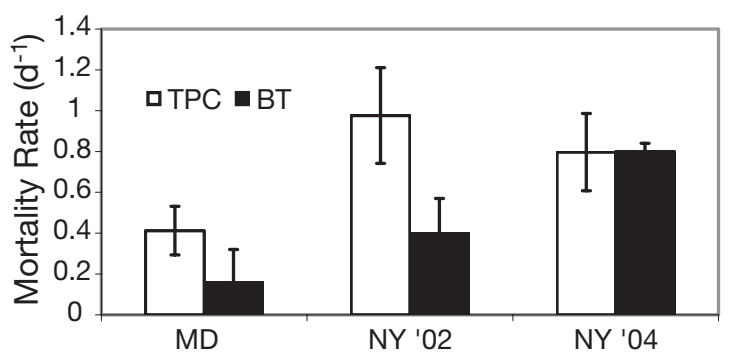

Fig. 7. Mortality rates for the total phytoplankton community (TPC) and Aureococcus anophagefferens (BT) averaged over the summer for MD and NY for 2002 and 2004. Error bars represent $\pm \mathrm{SE}$ of triplicate measurements 


\section{Planktonic community composition and the impact of zooplankton grazing}

The grazing impact of micro- and mesozooplankton on Aureococcus anophagefferens was nearly undetectable in MD, but there was evidence that a small grazer consumed brown tide. A. anophagefferens ex- perienced significantly decreased net growth rates in the $<5 \mu \mathrm{m}$ size fraction of the predator-exclusion experiments, compared to the $<10 \mu \mathrm{m}$ size fraction in MD (Fig. 6). This result implies a trophic cascade, whereby small zooplankton $(<5 \mu \mathrm{m})$ were able to proliferate in the absence of their predators in the $>5 \mu \mathrm{m}$ size class. Increased grazing pressure by $<5 \mu \mathrm{m}$ predators likely

Table 3. Microzooplankton grazing/seawater dilution experiment results for the mortality rate $\left(m, \mathrm{~d}^{-1}\right)$, the intrinsic growth rate for nutrient-amended incubations $\left(\mu_{\mathrm{n}}, \mathrm{d}^{-1}\right), \mu_{\mathrm{n}}$ corrected for nutrient additions $\left(\mu_{0}, \mathrm{~d}^{-1}\right)$, and the net rate of change $\left(k=\mu_{0}-m, \mathrm{~d}^{-1}\right)$. $\mathrm{r}^{2}$ values are for the regression of the dilution of seawater versus net growth rates. Rates are presented for the total phytoplankton community (TPC), Aureococcus anophagefferens (BT), photosynthetic picoeukaryotes (PEUK), and Synechococcus (SYN). $\mathrm{ND}$ : grazing was not detected; BD: counts were below the detection limit. Rates are means $( \pm \mathrm{SE})$ based on triplicate treatments

\begin{tabular}{|c|c|c|c|c|c|c|c|c|}
\hline & & & Date & $\mathrm{r}^{2}$ & $m$ & $\mu_{\mathrm{n}}$ & $\mu_{0}$ & $k$ \\
\hline \multirow[t]{3}{*}{ TPC } & 2002 & NY & $\begin{array}{l}23 \text { May } \\
04 \text { Jun } \\
18 \text { Jun } \\
11 \text { Jul } \\
08 \text { Aug }\end{array}$ & $\begin{array}{l}0.75 \\
0.88 \\
0.81 \\
0.64 \\
0.89\end{array}$ & $\begin{array}{r}0.46 \pm 0.08 \\
0.59 \pm 0.07 \\
0.76 \pm 0.12 \\
1.6 \pm 0.39 \\
1.5 \pm 0.17\end{array}$ & $\begin{array}{l}1.5 \pm 0.06 \\
2.0 \pm 0.05 \\
1.3 \pm 0.08 \\
2.0 \pm 0.27 \\
1.5 \pm 0.11\end{array}$ & $\begin{array}{r}0.95 \pm 0.06 \\
0.61 \pm 0.05 \\
-0.02 \pm 0.08 \\
1.3 \pm 0.27 \\
1.4 \pm 0.11\end{array}$ & $\begin{array}{r}0.49 \\
0.03 \\
-0.78 \\
-0.30 \\
-0.14\end{array}$ \\
\hline & 2003 & NY & $\begin{array}{c}19 \text { May } \\
03 \text { Jun } \\
16 \text { Jun } \\
30 \text { Jun } \\
21 \text { Jul }\end{array}$ & $\begin{array}{l}0.59 \\
\text { ND } \\
0.56 \\
0.75 \\
0.65\end{array}$ & $\begin{array}{r}0.74 \pm 0.20 \\
0.61 \pm 0.17 \\
1.1 \pm 0.20 \\
0.62 \pm 0.15\end{array}$ & $\begin{array}{r}1.4 \pm 0.13 \\
0.80 \pm 0.11 \\
2.6 \pm 0.13 \\
1.3 \pm 0.09\end{array}$ & $\begin{array}{l}0.96 \pm 0.13 \\
0.53 \pm 0.11 \\
1.37 \pm 0.13 \\
0.91 \pm 0.09\end{array}$ & $\begin{array}{r}0.22 \\
-0.08 \\
0.27 \\
0.29\end{array}$ \\
\hline & 2004 & $\mathrm{MD}$ & $\begin{array}{l}25 \text { May } \\
08 \text { Jun } \\
21 \text { Jun } \\
19 \text { Jul } \\
17 \text { Jun } \\
28 \text { Jun } \\
12 \text { Jul } \\
10 \text { Aug }\end{array}$ & $\begin{array}{l}\text { ND } \\
0.62 \\
0.45 \\
0.92 \\
0.60 \\
0.70 \\
0.63 \\
0.46\end{array}$ & $\begin{array}{r}0.84 \pm 0.21 \\
0.45 \pm 0.17 \\
1.1 \pm 0.10 \\
0.75 \pm 0.20 \\
0.31 \pm 0.07 \\
0.39 \pm 0.10 \\
0.20 \pm 0.09\end{array}$ & $\begin{array}{r}1.8 \pm 0.14 \\
1.5 \pm 0.11 \\
1.7 \pm 0.06 \\
0.98 \pm 0.13 \\
0.93 \pm 0.04 \\
1.2 \pm 0.06 \\
0.20 \pm 0.07\end{array}$ & $\begin{array}{r}1.42 \pm 0.14 \\
0.19 \pm 0.11 \\
0.52 \pm 0.06 \\
0.03 \pm 0.13 \\
0.18 \pm 0.04 \\
0.22 \pm 0.06 \\
-0.39 \pm 0.07\end{array}$ & $\begin{array}{r}0.58 \\
-0.26 \\
-0.58 \\
0.78 \\
0.49 \\
0.61 \\
-0.19\end{array}$ \\
\hline \multirow[t]{2}{*}{ BT } & 2002 & NY & $\begin{array}{l}23 \text { May } \\
04 \text { Jun } \\
18 \text { Jun } \\
11 \text { Jul } \\
08 \text { Aug }\end{array}$ & $\begin{array}{l}0.36 \\
\text { ND } \\
0.37 \\
0.47 \\
0.44\end{array}$ & $\begin{array}{l}0.53 \pm 0.22 \\
0.15 \pm 0.05 \\
0.34 \pm 0.11 \\
0.98 \pm 0.37\end{array}$ & & & \\
\hline & 2004 & NY & $\begin{array}{l}25 \text { May } \\
08 \text { Jun } \\
21 \mathrm{Jun} \\
19 \mathrm{Jul} \\
17 \mathrm{Jun} \\
28 \mathrm{Jun} \\
12 \mathrm{Jul} \\
10 \mathrm{Aug}\end{array}$ & $\begin{array}{l}\text { BD } \\
0.65 \\
0.44 \\
\text { BD } \\
\text { ND } \\
\text { ND } \\
0.76 \\
\text { ND }\end{array}$ & $\begin{array}{l}0.84 \pm 0.19 \\
0.76 \pm 0.27\end{array}$ & $\begin{array}{r}1.6 \pm 0.13 \\
0.25 \pm 0.17\end{array}$ & $\begin{array}{l}1.24 \pm 0.13 \\
0.07 \pm 0.17\end{array}$ & $\begin{array}{c}0.4 \\
-0.69\end{array}$ \\
\hline PEUK & 2004 & $\mathrm{MD}$ & $\begin{array}{l}25 \text { May } \\
08 \text { Jun } \\
21 \text { Jun } \\
19 \text { Jul } \\
17 \text { Jun } \\
28 \text { Jun } \\
13 \mathrm{Jul} \\
10 \mathrm{Aug}\end{array}$ & $\begin{array}{l}\text { ND } \\
0.88 \\
\text { ND } \\
0.62 \\
0.55 \\
\text { ND } \\
0.70 \\
0.58\end{array}$ & $\begin{array}{r}1.4 \pm 0.16 \\
\\
0.54 \pm 0.15 \\
0.30 \pm 0.09 \\
0.49 \pm 0.10 \\
0.60 \pm 0.16\end{array}$ & $\begin{array}{r}2.9 \pm 0.10 \\
0.39 \pm 0.10 \\
0.16 \pm 0.06 \\
0.08 \pm 0.07 \\
0.28 \pm 0.10\end{array}$ & $\begin{array}{r}2.3 \pm 0.10 \\
0.02 \pm 0.10 \\
-0.19 \pm 0.06 \\
-0.03 \pm 0.07 \\
0.34 \pm 0.10\end{array}$ & $\begin{array}{c}0.96 \\
\\
0.6 \\
-0.49 \\
-0.79 \\
-0.26\end{array}$ \\
\hline SYN & 2004 & MD & $\begin{array}{l}25 \text { May } \\
08 \text { Jun } \\
21 \mathrm{Jun} \\
19 \mathrm{Jul} \\
17 \mathrm{Jun} \\
28 \mathrm{Jun} \\
13 \mathrm{Jul} \\
10 \mathrm{Aug}\end{array}$ & $\begin{array}{l}\text { ND } \\
0.77 \\
\text { ND } \\
0.67 \\
0.74 \\
\text { ND } \\
\text { ND } \\
0.53\end{array}$ & $\begin{array}{r}1.8 \pm 0.31 \\
1.2 \pm 0.29 \\
0.36 \pm 0.07\end{array}$ & $\begin{array}{r}2.3 \pm 0.20 \\
1.1 \pm 0.19 \\
0.75 \pm 0.05\end{array}$ & $\begin{array}{r}2.8 \pm 0.20 \\
1.2 \pm 0.19 \\
0.05 \pm 0.05\end{array}$ & $\begin{array}{r}0.96 \\
0.01 \\
-0.31\end{array}$ \\
\hline
\end{tabular}


caused lower net growth rates for A. anophagefferens (Fig. 6; Calbet \& Landry 1999). This hypothesis is further supported by the dramatic increase in $A$. anophagefferens net growth rates when plankton $>3 \mu \mathrm{m}$ were removed (Fig. 6).

The small heterotrophic nanoplankter Paulinella ovalis was extremely abundant in the $<5 \mu \mathrm{m}$ size class in MD (up to $50 \%$ of total nanoplankton; Table 2). There was a significantly greater percentage of P. ovalis $(<5 \mu \mathrm{m})$ in MD during the brown tide than in NY during 2004. P. ovalis was completely absent from NY samples in 2003. Since $P$. ovalis appears to thrive during brown tides, while other protozoans are diminished (Johnson et al. 1988, present study), this heterotroph could be the consumer responsible for the grazing pressure on Aureococcus anophagefferens in the $<5 \mu \mathrm{m}$ size fraction of the trophic cascade experiments in MD. Moreover, $P$. ovalis is likely grazed by a species $>5 \mu \mathrm{m}$ in size, which would account for the higher growth rates of $A$. anophagefferens in the $<10 \mu \mathrm{m}$ size fraction (Fig. 6). However, we suspect that this species may avoid $A$. anophagefferens and instead apply strong grazing pressure on the non-Aureococcus picophytoplankton in MD (Fig. 2). In past research, Paulinella spp. have been shown to consume singlecelled cyanobacteria, such as Synechococcus spp. (Johnson et al. 1988, Lukavasky \& Cepak 1992), which is known to compete with Aureococcus spp. for dominance during summer months in mid-Atlantic estuaries (Gobler et al. 2004, 2005, Sieracki et al. 2004). This process would yield reduced competition for nutrients among small algae, which may otherwise have a similar affinity for low concentrations of nutrients (Raven \& Kubler 2002), potentially allowing for a picoplankton which is ungrazed (Aureococcus) to dominate. Since the experimental work in NY also yielded low $A$. anophagefferens net growth rates in the $<5 \mu \mathrm{m}$ experimental treatments, despite the absence or rarity of $P$. ovalis, there are likely other, currently unidentified, small grazers in these systems that consume brown tide and other picoplankton.

Copepod nauplii are another potentially important grazer of Aureococcus anophagefferens, based on the size particles that these zooplankton are capable of capturing, and may also represent a trophic link between $A$. anophagefferens and mesozooplankton (Lonsdale et al. 1996). Copepod nauplii were the dominant zooplankton in the $>64 \mu \mathrm{m}$ size category at all sites studied (Fig. 4), a finding consistent with previously published reports on Long Island bays (Lonsdale et al. 1996). A recent laboratory study investigating nauplii grazing on $A$. anophagefferens suggested that nauplii can rapidly graze some, but not all, toxic strains of this alga and thus may contribute to the demise of bloom events (Smith 2005). Nauplii were significantly more abundant in MD from mid-June through August than in NY in 2003, but not in 2004 (t-test, p < 0.05). Moreover, between 17 June and 28 June 2004 in MD, nauplii abundance increased significantly (14-fold; $t$-test, $\mathrm{p}<0.05$; Fig. 4 ) in conjunction with a decrease in $A$. anophagefferens densities there, suggesting that the increase in naupliar abundance and associated grazing may have reduced bloom densities. Alternatively, if nauplii are inhibited by wild strains of $A$. anophagefferens that bloom in the field, enhanced nauplii abundances observed in late June may have been caused by the waning $A$. anophagefferens densities, which may have been due to other factors such as higher temperature or viral lysis (reviewed in Gobler et al. 2005).

Evidence for a trophic cascade from mesozooplankton to Aureococcus anophagefferens

Mesozooplankton have the potential to influence brown tide dynamics by directly consuming Aureococcus anophagefferens, co-occurring algae, and/or micro- or nanoplanktonic zooplankton that might prey on the brown tide alga or competing algae (Calbet et al. 2003, Sieracki et al. 2004). In MD, Aureococcus anophagefferens experienced either no grazing or lower grazing by mesozooplankton compared to other autotrophic populations within Chincoteague Bay. For example, the addition of mesozooplankton in MD caused photosynthetic picoeukaryote and Synechococcus spp. net growth rates to decrease, while $A$. anophagefferens densities were not significantly affected (Fig. 5). Coupled with the microzooplankton grazing/dilution experiments, which generally did not yield significant grazing on $A$. anophagefferens, but did on other picoplankton on most dates at this site, it appears that zooplankton selected against the brown tide alga in MD (Table 3; Gobler et al. 2002, 2004, Caron et al. 2004). This conclusion is in agreement with the experimental results, which indicated that the enrichment of mesozooplankton had no effect on $A$. anophagefferens in MD. During the same mesozooplankton-addition experiments, photosynthetic picoeukaryotes and Synechococcus spp. experienced net negative growth rates, which were often significantly lower than control treatments (Fig. 5). These findings imply the existence of an even number of trophic levels ( 2 or 4 ) from mesozooplankton to nonAureococcus picophytoplankton in embayments with blooms. Although mesozooplankton may directly graze on picophytoplankton (a 2-level food chain), as suggested by Calbet (2001), experiments removing meso-, micro-, and nanoplankton suggested that the system was likely more complex, with mesozooplank- 
ton consuming a secondary consumer that preys on a primary consumer of picoplankton (a 4-level food chain and a trophic cascade; Fig. 6; Calbet \& Landry 1999, Sieracki et al. 2004, Deonarine 2005).

A shift in planktonic community structure, which caused the brown tide alga to be negatively affected by the addition of mesozooplankton, appeared to have occurred at the NY site in mid-June during 2003 and 2004. The addition of mesozooplankton significantly decreased Aureococcus anophagefferens net growth rates, whereas $A$. anophagefferens in MD was not affected by these additions. There was a similar disparity in the response of Synechococcus spp. and photosynthetic picoeukaryote net growth rates between MD and NY. In MD, non-Aureococcus net growth rates were always significantly decreased by mesozooplankton additions, but, in NY, the net growth rates of all groups of picoplankton were only significantly affected in late July of both years ( $t$-test, $p<0.05$; Fig. 5). These results suggest that fundamental differences in the plankton community structure and function existed between these sites. Assuming a 4-level food chain, the addition of mesozooplankton in MD likely applies strong grazing pressure to microzooplankton, which in turn releases nanozooplankton from predation, yielding enhanced grazing on picoplankton, with the exception of $A$. anophagefferens, which is unaffected (Fig. 5). In NY, it is possible that similar food chain linkages strengthened through the summer such that these effects were only observed later in the summer.

In NY, in 2003, as the summer progressed, picoplankton, including Aureococcus anophagefferens, were negatively impacted by mesozooplankton enrichment on later sampling dates (Fig. 5). This suggests that, over the course of June and July, mesozooplankton developed a negative trophic relationship with the brown tide alga and other picophytoplankton, as described above. However, in 2004, the final mesozooplankton-enrichment experiments in NY yielded significantly increased net growth rates of Synechococcus spp. and photosynthetic picoeukaryotes (Fig. 5) and a significantly decreased net growth rate for $A$. anophagefferens, indicating grazers were preferentially consuming brown tide. A more permanent shift to preferential grazing on Aureococcus spp. in NY compared to other populations could potentially suppress future brown tides in this region.

\section{Role of zooplankton in the onset and demise of brown tides}

Aureococcus anophagefferens was not a recognized member of the phytoplankton community of NY estuaries prior to 1985 and of MD estuaries prior to 1994
(Trice et al. 2004, Gobler et al. 2005). Moreover, A. anophagefferens possesses pigment and nutrientuptake characteristics that are similar to many openocean phytoplankton species (Yentsch et al. 1989, Lomas et al. 1996) and most other pelagophytes are oceanic (Thomsen 1986, Andersen et al. 1993). As such, some have speculated that $A$. anophagefferens is an expatriate ocean species, which was introduced into estuaries that now host blooms (Bidigare 1989, Yentsch et al. 1989, Popels et al. 2003), perhaps by anthropogenic means (Doblin et al. 2004). Were this the case, such an invasive species, which is not palatable by many benthic and pelagic grazers (as reviewed by Gobler et al. 2005), would be expected to bloom with minimal predation loses, as was observed formally in NY (Gobler et al. 2002) and currently in MD (present study), so long as the prevailing nutrient regime was favorable for this species (high levels of dissolved organic nitrogen; Gobler et al. 2002, 2004, 2005, present study). Since studies of individual protozoan grazers have shown that some species are adversely affected by $A$. anophagefferens, while others can consume this species (Caron et al. 1989, 2004, their unpubl. data), consecutive blooms in the field would be expected to alter zooplankton community composition, with Aureococcus-tolerant species thriving and those adversely affected becoming less prolific. The Peconic Estuary experienced more consistent, highdensity blooms than any other system during the 1980s and early 1990s, and stopped experiencing blooms after 1995 (as reviewed in Gobler et al. 2005). Estuaries on the south shore of Long Island (such as Quantuck Bay) experienced blooms that became more chronic during the 1990s and early 2000s, but have not experienced blooms since 2002 (as reviewed in Gobler et al. 2005). It is possible that these patterns of bloom occurrence are being driven by the emergence and dominance of zooplankton grazers, which are capable of consuming $A$. anophagefferens, a pattern which would be consistent with previous observations of rapid community evolution of zooplankton exposed to harmful algal blooms (Hairston et al. 2001, Colin \& Dam 2002). If such a mechanism were in place, MD estuaries, which did not experience blooms until the mid- to late 1990s, may begin to have more sporadic, less intense blooms in the future if zooplankton that can consume A. anophagefferens begin to dominate the plankton there.

Acknowledgements. This research was supported by NOAA, Coastal Ocean Program ECOHAB No. NA16OP2790 awarded to C.J.G. and Grant NA16OP2791 awarded to D. J. Lonsdale. We thank Dr. Jackie L. Collier for technical advice. We are grateful to Rebecca Schaffner and Dr. O. Roger Anderson for sample analysis. Our gratitude also goes to George Boneillo, 
who supplied some field data from MD. We thank The Marine Science Consortium (Greenbackville, Virginia) for the use of their facilities as well as the Harvey family of Maryland for the use of their property. We thank the members of the Gobler laboratory who assisted with field research, experimental setup, and sample analysis, and in particular Jeffrey Krause, Patrick Curran, Danielle Thibault, Timothy Davis, Michelle Weiss, Amanda Burson, and Florian Koch. This is Contribution Number 1320 from MSRC and 198 from ECOHAB.

\section{LITERATURE CITED}

Andersen RA, Sauners GW, Paskind MP, Sexton JP (1993) Ultrastructure and 18S rRNA gene sequence for Pelagomonas calceolata gen. et sp. nov. and the description of a new algal class, the Pelagophyceae class nov. J Phycol 29:701-715

Bidigare RR (1989) Photosynthetic pigment composition of the brown tide alga: unique chlorophyll and carotenoid derivatives. In: Cosper EM, Bricelj VM, Carpenter EJ (eds) Novel phytoplankton blooms: causes and impacts of recurrent brown tides and other unusual blooms. SpringerVerlag, New York, p 57-75

Calbet A (2001) Mesozooplankton grazing effect on primary production: a global comparative analysis in marine ecosystems. Limnol Oceanogr 46:1824-1830

Calbet A, Landry MR (1999) Mesozooplankton influences on the microbial food web: direct and indirect trophic interactions in the oligotrophic open ocean. Limnol Oceanogr 44: $1370-1380$

Calbet A, Vaqué D, Felipe J, Vila M, Sala MM, Alcaraz M, Estrada M (2003) Relative grazing impact of microzooplankton and mesozooplankton on a bloom of the toxic dinoflagellate Alexandrium minutum. Mar Ecol Prog Ser 259:303-309

Caron DA, Lim EL, Kunze H, Cosper EM, Anderson DM (1989) Trophic interactions between nano- and microzooplankton and the brown tide. In: Cosper EM, Bricelj VM, Carpenter EJ (eds) Novel phytoplankton blooms: causes and impacts of recurrent brown tides and other unusual blooms. Springer-Verlag, New York, p 263-294

Caron DA, Dennett MR, Moran DM, Schaffner RA, Lonsdale DJ, Gobler CJ, Nuzzi R, McLean TI (2003) Development and application of a monoclonal-antibody technique for counting Aureococcus anophagefferens, an alga causing recurrent brown tide in the mid-Atlantic United States. Appl Environ Microbiol 69:5492-5502

Caron DA, Gobler CJ, Lonsdale DJ, Cerrato RM and 6 others (2004) Microbial herbivory on the brown tide alga, Aureococcus anophagefferens: results from natural ecosystems, mesocosms, and laboratory experiments. Harmful Algae 3:439-457

Colin SP, Dam HG (2002) Latitudinal differentiation in the effects of the toxic dinoflagellate Alexandrium spp. on the feeding and reproduction of populations of the copepod Acartia hudsonica. Harmful Algae 1:113-125

Deonarine SN (2005) The impact of zooplankton grazing and trophic structure on the mortality of Aureococcus anophagefferens in US mid-Atlantic estuaries. MS thesis, Stony Brook University, Stony Brook, NY

Doblin MA, Popels LC, Coyne KJ, Hutchins DA, Cary SC, Dobbs FC (2004) Transport of the harmful bloom alga Aureococcus anophagefferens by ocean-going ships and coastal boats. Appl Environ Microbiol 70:6495-6500

Gallegos CL (1989) Microzooplankton grazing on phytoplankton in the Rhode River, Maryland: non-linear feed- ing kinetics. Mar Ecol Prog Ser 57:23-33

Gobler CJ, Sañudo-Wilhelmy SA (2001) Temporal variability of groundwater seepage and brown tide blooms in a Long Island embayment. Mar Ecol Prog Ser 217:299-309

Gobler CJ, Renaghan MJ, Buck NJ (2002) Impacts of nutrients and grazing mortality on the abundance of Aureococcus anophagefferens during a New York brown tide bloom. Limnol Oceanogr 47:129-141

Gobler CJ, Deonarine S, Leigh-Bell J, Downes-Gastrich M, Anderson OR, Wilhelm SW (2004) Ecology of phytoplankton communities dominated by Aureococcus anophagefferens: the role of viruses, nutrients, and microzooplankton grazing. Harmful Algae 3:471-483

Gobler CJ, Lonsdale DJ, Boyer GL (2005) A review of the causes, impacts, and potential management of harmful brown tide blooms caused by Aureococcus anophagefferens. Estuaries 28:726-749

Greenfield DI, Lonsdale DJ (2002) Mortality and growth of juvenile hard clams Mercenaria mercenaria during brown tide. Mar Biol 141:1045-1050

Hairston NG, Holtmeier CL, Lampert W, Weider LJ and 5 others (2001) Natural selection for grazer resistance to toxic cyanobacteria: Evolution of phenotypic plasticity? Evolution 55:2203-2214

Hasle GR (1978) The inverted microscope method. Monogr Oceanogr Methodol 6:88-96

Johnson PW, Hargraves PE, Sieburth JM (1988) Ultrastructure and ecology of Calycomonas ovalis Wulff, 1919 (Chrysophyceae) and its redescription as a testate rhizopod, Paulinella ovalis N. Comb. (Filosea: Euglyphina). J Protozool 35:618-626

Jones MN (1984) Nitrate reduction by shaking with cadmium: alternative to cadmium columns. Water Res 18:636-643

Kiørboe T (1998) Population regulation and role of mesozooplankton in shaping marine pelagic food webs. Hydrobiologia 363:13-27

Klein Breteler WCM, Schogt N, Baas M, Schouten S, Kraay GW (1999) Trophic upgrading of food quality by protozoans enhancing copepod growth: role of essential lipids. Mar Biol 135:191-198

Landry MR, Hassett RP (1982) Estimating the grazing impact of marine micro-zooplankton. Mar Biol 67:283-288

Landry MR, Kirshtein J, Constantinou J (1995) A refined dilution technique for measuring the community grazing impact of microzooplankton, with experimental tests in the central equatorial Pacific. Mar Ecol Prog Ser 120: $53-63$

Lomas MW, Glibert PM, Berg GM (1996) Characterization of nitrogen uptake by natural populations of Aureococcus anophagefferens (Chrysophyceae) as a function of incubation duration, substrate concentration, light, and temperature. J Phycol 32:907-916

Lonsdale DJ, Cosper EM, Kim WS, Doall M, Divadeenam A, Jonasdottir SH (1996) Food web interactions in the plankton of Long Island bays, with preliminary observations on brown tide effects. Mar Ecol Prog Ser 134:247-263

Lukavasky J, Cepak V (1992) DAPI fluorescent staining of DNA material in cyanelles of the rhizopod Paulinella chromatophora Lauterb. Arch Protistenkd 142:207-212

Newell BS, Morgan B, Cundy J (1967) The determination of urea in seawater. J Mar Res 25:201-202

Omori M, Ikeda T (1984) Methods in marine zooplankton ecology. John Wiley \& Sons, New York

Parsons TR, Maita Y, Lalli CM (1984) A manual of chemical and biological methods for seawater analysis. Pergamon Press, New York

Popels LC, Coyne KJ, Forbes R, Pustizzi F, Gobler CJ, Cary 
SC, Hutchins DA (2003) The use of quantitative polymerase chain reaction for the detection and enumeration of the harmful alga Aureococcus anophagefferens in environmental samples. Limnol Oceanogr Methods 1:92-102

Raven JA, Kubler JE (2002) New light on the scaling of metabolic rate with the size of algae. J Phycol 38:11-16

Sieburth JM, Smetacek V, Lenz J (1978) Pelagic ecosystem structure: heterotrophic compartments of the plankton and their relationship to plankton size fractions. Limnol Oceanogr 23:1256-1263

Sieracki ME, Gobler CJ, Cucci TL, Thier EC, Gilg IC, Keller MD (2004) Pico- and nanoplankton dynamics during bloom initiation of Aureococcus in a Long Island, NY bay. Harmful Algae 3:459-470

Smith J (2005) Feeding behavior and development of Acartia tonsa nauplii on the brown tide alga Aureococcus anophagefferens. MS thesis, Stony Brook University, Stony Brook, NY

Taylor GT, Gobler CJ, Sañudo-Wilhelmy SA (2006) Speciation and concentrations of dissolved nitrogen as determi-

Editorial responsibility: Robert W. Sanders,

Philadelphia, Pennsylvania, USA nants of brown tide Aureococcus anophagefferens initiation. Mar Ecol Prog Ser 312:67-83

Thomsen HA (1986) A survey of the smallest eucaryotic organisms of the marine phytoplankton. In: Platt $\mathrm{T}, \mathrm{Li}$ WKW (eds) Photosynthetic picoplankton. Can Bull Fish Aquat Sci 214:121-158

Trice TM, Glibert PM, Lea C, Van Heukelem L (2004) HPLC pigment records provide evidence of past blooms of Aureococcus anophagefferens in the coastal bays of Maryland and Virginia, USA. Harmful Algae 3:295-304

Valderama JC (1981) The simultaneous analysis of total nitrogen and phosphorous in natural waters. Mar Chem 10: 109-122

Yentsch CS, Phinney DA, Shapiro LP (1989) Adsorption and fluorescent characteristics of the brown tide chrysophyte: its role on light reduction in coastal marine environments. In: Cosper EM, Bricelj VM, Carpenter EJ (eds) Novel phytoplankton blooms: causes and impacts of recurrent brown tides and other unusual blooms. Springer-Verlag, New York, p 77-85

Submitted: December 15, 2005; Accepted: May 9, 2006 Proofs received from author(s): August 8, 2006 